\title{
A Day at the Office
}

\section{A Day at the Office: What if "Later" Never Comes? Four Tips for Volunteering Abroad Now}

\author{
Douglas W. Lundy MD, MBA
}

\begin{abstract}
T $\mathrm{n}$ my previous column, I highlighted one concern that may be common among private-practicing orthopaedic surgeons: Retiring without experiencing all of the opportunities that orthopaedic surgery offers [1]. I bundled these opportunities into four categories: Charity, research, teaching, and leadership. Although all four of these endeavors are vital, to me, charitable work is the most fulfilling.
\end{abstract}

A note from the Editor in Chief:

We are pleased to present the next installment of A Day at the Office. In this column, private practice orthopaedic surgeon Douglas W. Lundy $M D, M B A$, provides perspective on the pressures that orthopaedic surgeons face on a typical "day at the office," as well as a broader viewpoint about trends in nonacademic clinical-care settings.

The author certifies that neither he, nor any members of his immediate family, has have any no commercial associations (such as consultancies, stock ownership, equity interest, patent/licensing arrangements, etc.) that might pose a conflict of interest in connection with the submitted article. All ICMJE Conflict of Interest Forms for authors and Clinical Orthopaedics and Related Research ${ }^{\mathbb{R}}$ editors and board members are on file with the publication and can be viewed on request.

The opinions expressed are those of the writers, and do not reflect the opinion or
It is easy to forget that large portions of the globe are in such desperate need, and that our time, skill, and compassion are ours to share. In 2003, I volunteered abroad for the first time in Ulaan Baatar, Mongolia to teach Mongolian trauma surgeons some of our approaches to patients with musculoskeletal injuries. The decision to volunteer abroad changed my purpose as an orthopaedic trauma surgeon. Since that time, I have been on 15 other foreign medical mission trips in Asia, Africa, Eastern Europe, and Haiti.

At the time of that first trip, I had only been in private practice for 3 years, and I was planning to go on a medical mission when I was more financially stable and my children were older. In private practice, everything depends on our productivity. The stress of developing your practice

policy of $C O R R^{\mathbb{R}}$ or The Association of Bone and Joint Surgeons ${ }^{\circledR}$.

D. W. Lundy MD, MBA ( $\square)$

Resurgens Orthopaedics, 61 Whitcher

Street, Suite 1100, Marietta, GA 30126,

USA

e-mail: lundydw@resurgens.com while trying to be a worthy spouse, parent, and friend can be overwhelming, and I suspected that the "moreexperienced me" would volunteer abroad once I had fewer family and professional demands.

But plans change. I received a message from an organization I belonged to that needed an orthopaedic trauma surgeon to teach in Mongolia. It struck me that I didn't have to wait until later in my career to volunteer abroad. Why wait? What if later never comes?

Although there are clear-cut healthcare delivery disparities in the United States, this inequity is far more dramatic in other parts of the world. There is a little-known concept described as the $10 / 40$ window. Approximately $82 \%$ of the poorest people in the world live between $10^{\circ} \mathrm{N}$ and $40^{\circ} \mathrm{N}$ parallels, and there is tremendous need for quality orthopaedic care in these countries [2]. Indeed, there are several good reasons why we should participate in charity work at all phases of our work life, but volunteering abroad deserves careful consideration. Here are some tips the private practice surgeon should consider before volunteering his or her time. 


\section{A Day at the Office}

\section{Conduct a Self-inventory}

A self-inventory is a self-reflective exercise that compels you to look inward and discover who you are, and more importantly, the type of person you want to be. This self-inventory must go beyond the here and now. Say, for example, that you run a successful private practice. What, specifically, are you looking for as you consider an overseas volunteer opportunity? Could it be that you need to stretch your horizons and your comfort zone? Is it time to revive your love of orthopaedic surgery? Carefully seek this answer, because if the trip you are considering does not involve elements that will provide what you are looking for, the trip will not fulfill you.

Much of your inventory is about seeking who you want to be. At the end of your career, what kind of person will you look back upon? Was it someone who amassed wealth and lived a lavish lifestyle, or one who constantly invested in the lives, the success, and the welfare of others?

\section{Consider Your Practice}

Talk with your partners and clinical staff. Who will cover your patients and the demands of the practice in your absence? Although much less common than in previous years, there still are places around the world without cell phone coverage. Can you go without checking in with the office every day? What if a partner or other colleague wants to go with you? How will that affect your practice back home?

Answer these questions honestly. Perhaps while answering your tough questions you find that now is not a good time to leave your practice. There are plenty of opportunities here in the United States as well as in Central America for us to help those in need. These endeavors are every bit as important. There are a litany of organizations that provide surgeons the opportunity to serve in the developing world. I suggest that the reader decide if they would prefer a faith-based or secular organization, and start your search with those parameters.

\section{Talk to Your Family}

Your family will suffer a degree of loss while you are gone. Family members may not understand why you feel compelled to do this, and they may have reasonable objections. It is critical to hear and understand their views and concerns before you embark.

On the other hand, I have known many orthopaedic surgeons who took their entire family abroad into resource-poor conditions to serve the needy. Without exception, the children of these families have told me that this was their favorite "vacation" and the best family memory they have. Most of our children live privileged lives, and allowing them to see the "real world" can have lasting and profound positive effects on their world views.

\section{Don't Go it Alone}

As stated previously, there are many organizations that will provide you opportunities to serve both in the United States and the rest of the world. Orthopaedics Overseas (https://hvousa.org/ ourwork/programs/orthopaedics/) and Doctors Without Borders (http:// www.doctorswithoutborders.org/) are two secular groups that will reduce the logistical hassle of these endeavors. SIGN does tremendous work designing and manufacturing orthopaedic implants to under-resourced hospitals via donation or on a cost-reimbursement basis (https://signfracturecare. org/get-involved/volunteer-overseas/).

Nearly every major religious movement has charitable organizations that will facilitate these trips, albeit with a spiritual component. I work extensively with the Christian Medical and Dental Association through the Pan African Academy of Christian Surgeons (www.paacs.net). 


\section{A Day at the Office}

All of these organizations are run by dedicated volunteers who are passionate about their specific cause. But after you ascertain that the group has enough experience to efficiently coordinate the trip, research the politics or agenda associated with an organization to ensure your personal comfort level with the group and its culture.
Don't underestimate what is involved when one volunteers overseas; the reward and the sacrifice are substantial. The younger surgeon may feel that he or she is not adequately experienced to do this, but I have found that the most-capable surgeons in the mission setting are the ones that are unafraid to accept challenges, regardless of age.

\section{References}

1. Lundy DW. A Day at the Office: Smooth transitions-Setting up the next phase of a professional life. Clin Orthop Relat Res. 2017;475:1966-1968.

2. The Joshua Project. What is the $10 / 40$ window? Available at: https:// joshuaproject.net/resources/articles/ 10_40_window. Accessed August 28, 2017. 